\title{
Beyond the Characters and the Reader? Digital Discussions on Intersectionality in The Murderer's Ape
}

\author{
Annbritt Palo ${ }^{1}$ (D) Lena Manderstedt $^{1}$
}

Published online: 4 October 2017

(C) The Author(s) 2017. This article is an open access publication

\begin{abstract}
This article presents an analysis of a recent, award-winning Swedish novel for children and young adults, The Murderer's Ape by Jakob Wegelius, and digitally published reviews of the novel. In the first part of the paper, we provide an intersectional analysis of the novel, focusing on gender, profession, species and class. The protagonist and narrator of The Murderer's Ape is not easily categorized, as she is a mute but literate, highly intelligent and technically proficient gorilla in a man's world; an ape among human beings, a working engineer and not a pet or an attraction at a zoo. Neither class nor social standing constrain her as they do the human fictional characters. In the second part of the paper, we contrast commentaries by professional readers with comments from young readers, paying particular attention to how they have responded to the protagonist. The overarching aim is to examine how features admired by critics and professional readers are, in practice, understood by engaged, active readers, including children. Some intersectional categories represent acquired qualities, whereas others represent socially set boundaries. Posthumanist and intersectional perspectives provide tools to understand Sally Jones' position beyond both the other fictional characters and the
\end{abstract}

\footnotetext{
Annbritt Palo is a senior lecturer in Swedish and Education at Luleå University of Technology. She is primarily interested in issues of literature, literature and education, gender, intersectionality, media literacy and curriculum theory.

Lena Manderstedt works as a senior lecturer in Swedish and Education at Luleå University of Technology. Her research interests are mainly literature, literature and education in relation to the media, children, youth and online cultures and different aspects of ideology and power.
}

Annbritt Palo

Annbritt.Palo@1tu.se

Lena Manderstedt

Lena.Manderstedt@1tu.se

1 Department of Arts, Culture and Education, Luleå University of Technology, 971 87, Luleå, Sweden 
readers. The analyses reveal differences between the readings of gender, profession and class by professional and young readers, but for both categories, the readers' reactions to questions pertaining to species are pivotal in their readings of the novel.

Keywords Children's literature · Reader-response · Online readers · Intersectionality $\cdot$ Posthumanism

'What I need, then,' the maharaja said, 'is an informer of my own inside the zenana. A spy! (...) The question is who?'(...) 'Obviously my informer cannot be a man, since I'm the only man allowed into the zenana. Nor, however, can it be a woman, as a woman is not allowed to leave' (Jakob Wegelius, 2017, p. 320). ${ }^{1}$

The Maharaja's choice falls upon Sally Jones. This quote from Wegelius' novel for children and young adults, Mördarens apa (2014), illustrates a key aspect of the novel, namely that the protagonist and narrator cannot easily be categorized. Sally Jones is intelligent, resourceful and mute, which makes her a suitable spy. Since she is neither a man, nor a woman, but rather a gorilla, she can enter and leave the harem. Sally Jones is a literate, professionally skilled animal among human beings, and a female in a predominantly male world. She is the protagonist of two novels for children and young adults, a pictorial novel, Legenden om Sally Jones ["The Legend of Sally Jones"] and The Murderer's Ape. As author and illustrator, in 2008 and 2014 respectively, Wegelius was awarded the August Prize for the Best Swedish Children's Book of the Year with both books. In 2015, he was also awarded the Nordic Council Children and Young People's Literature Prize for Mördarens apa.

Scholars in the field of children's literature have paid much attention to the affordances of literary texts (Maria Nikolajeva, 2014). This study also begins with such an approach as we examine the novel top-down, using the feminist concept of intersectionality to highlight the 'in-betweenness' of the protagonist. We complement this analysis with empirical research on how other readers have experienced this aspect of the novel. Some empirical studies of young readers have been carried out (Margaret Mackey, 2011; Lawrence Sipe, 2007), but critics such as Geoff Hall (2005, 2009) have called for more empirical research regarding young readers' responses to literature, which has resulted in the blossoming of a new school of research, the so-called 'scientific study of literature' with a journal of the same name as well as international research societies, such as International Society for the Empirical Study of Literature (IGEL). By examining the text alongside the readings of others, we aim to create a fuller understanding of how the affordances of the text actually impact on readers.

\footnotetext{
1 All Swedish, Norwegian or Danish quotes from online texts have been translated into English by the authors of this article, who have contributed equally, but quotes from the novel come from the English translation, from 2017, by Peter Graves. In Graves' translation, the word "maharaja” is not capitalized.
} 
When young readers' responses have been considered, scholars such as Martha Nussbaum (2003) and Joseph A. Appleyard (1994) are often interested in responses to fictional characters. With this article, we want to contribute to the empirical research on readers' responses, building on naturally occurring data, namely digitally published reviews and comments which were not produced as the result of a research design or for research purposes. Our study began with a broad search using the search term "Jakob Wegelius Mördarens apa". From the vast material this produced, texts dealing with readers' responses to the novel were collected. These posts were then inductively analysed, and four main categories of power asymmetries were identified. Thus, the material offers an insight into what engaged readers, both adults and children, react to when reading a complex novel.

The Internet offers opportunities to discuss the novel in various social media online. Online communication about literature has, according to Mattias Aronsson (2015), been less explored in Sweden, although the number of children and young adults using the internet more than three hours per day has more than doubled in 10 years (Statens medieråd, 2017). Some studies exist: Ann Steiner's (2012a, b) and Petra Söderlund's (2012) research has focused upon adult readers, whereas Lena Manderstedt and Annbritt Palo's studies (2009, 2015, 2017 ${ }^{2}$ ) and Palo and Manderstedt's studies (2011, 2016) mainly focus on young readers' literary discussions in digital environments.

Reading and discussing books is a socially acceptable practice, and online and offline friendship communities have an impact on what young people read (Judith Hayn et al., 2016). In some cases, libraries and schools provide venues, such as public blogs and discussion forums, where young people may discuss the books that they have read. Many online venues for discussing literature are, however, not linked to a school context, but to a networking community. Blogging and fan fiction are the most researched areas within studies of young readers' responses to text. The technology has had a double impact, allowing online readers the possibility of "creating new ways to discuss, dissect and celebrate their favourite stories" (Marcella Purnama and Mark Davis, 2016) and boosting the sales of young adult literature. Consequently, it can be argued that research on young people's reading should include digital environments, since they allow access to real readers' responses. These digital environments offer engaged readers a context for discussing literature, and allow researchers to hear the voices of untrained as well as trained readers.

The main differences between previous studies and the present study is that we combine an intersectional analysis of the literary text and the online posts containing comments on the novel. The combination allows us to address both the relation between society and literary text and between the literary text and the reception of it, as suggested by Lars Furuland (2012/1997). Thus, this study is the result of an integrated analysis, focusing readers of different types and the topics of their online discussions on a particular work of literature, namely The Murderer's Ape.

The aims of this article are twofold. In the first part of the paper, we provide an intersectional analysis of the novel, highlighting Sally Jones' position beyond the

\footnotetext{
2 In review.
} 
knowledge of the other fictional characters. The second part examines how readers have responded to the protagonist's intersectionality by looking closely at writings presented in interactive, digital environments. These responses have been divided into two categories: those by "connoisseurs" (professionals, such as critics and journalists) and "consumers" who read for pleasure. The overarching aim of these two studies is to examine how features admired by critics and professional readers are, in practice, understood by engaged, active readers, including children. The readers who post comments on their readings are amongst the most engaged as they have chosen to respond publicly. Therefore, virtual ethnography (cf. Christine Hine, 2015; Robert Kozinets, 2010), called 'netnography' by Kozinets, was combined with an intersectional analysis in order to analyse the online material pertaining to The Murderer's Ape. Methodologically, researchers in this field tend to interact with informants to a higher extent than we did. We have tried to understand the interactions in forums without communicating directly with the participants, although there was some interaction in terms of attendance and visitor statistics. However, no data came from closed forums. An overview of the empirical data is presented in Table 1.

There are some ethical aspects to consider when collecting data on open Web sites. We have striven to provide the necessary information without identifying individuals, especially their names. Since all messages are posted publicly, we have not coded names, but entered them where the authors are acting professionally and in other cases chosen nicknames where possible. Establishing the identity of the person who posted a blog or a comment is not always possible. We assume that most readers are truthful, as shown by other researchers (cf. Kristian Daneback, 2006; Malin Sveningsson et al., 2003). As researchers must document the empirical material (cf. AoIR, 2012), printouts and printscreens have been made.

Table 1 An overview of the empirical data for this study

\begin{tabular}{ll}
\hline Type of data & $\begin{array}{l}\text { The novel The Murderer's Ape }(2017)^{\mathrm{a}} \\
\text { Reviews, YouTube movies, pods, blog posts, Instagram posts, Twitter messages }\end{array}$ \\
Search criteria & $\begin{array}{l}\text { Search words "Jakob Wegelius Mördarens apa" (Google search) } \\
\text { Posts with some degree of interactivity, for example comments, or an application } \\
\text { allowing readers to "like" or "dislike" the text } \\
\text { Date of access }\end{array}$ \\
$\begin{array}{c}\text { Numbers of } \\
\text { informants }\end{array}$ & 97 \\
$\begin{array}{c}\text { Categories of } \\
\text { informants }\end{array}$ & Connoisseurs (47), mainly journalists and librarians \\
& Consumers (50)
\end{tabular}

\footnotetext{
a Sipe (2007) argues for a semiotic theoretical perspective on picture books, and as Wegelius' book is illustrated by the author himself, this could provide material for the analysis. However, as the readers' posts barely mention the illustrations, we have chosen not to analyse the illustrations for this article

${ }^{\mathrm{b}}$ The online posts are, primarily, in Swedish, since the novel is in Swedish and only recently has been translated into other languages

${ }^{\mathrm{c}}$ In this article, only connoisseurs and young consumers have been quoted
} 


\section{In-Betweenness and Outsiderness: An Analysis of the Novel}

The protagonist of The Murderer's Ape is a gorilla named Sally Jones. After a life as a master thief, circus monster, and truck driver, she ends up on a boat as an engineer. ${ }^{3}$ The story of The Murderer's Ape is told retrospectively and in writing about the events leading to her friend, the Chief, wrongly being convicted of murder, and Sally Jones hunted as "the murderer's ape". In her quest for the truth, Sally Jones is assisted by humans, in particular a factory worker/fado singer and an instrument repair shop owner. As Sally Jones is non-human and mute, this immediately puts her beyond the scope of the other fictional characters. Despite the novel being marketed as children's literature, there is no child character in the story. Therefore, it is possible to presume that understanding the fictional character, as well as making meaning, is not to be achieved through direct identification but through a complex framework of intersecting social identities connected to questions of domination and discrimination. Intersectional analyses examine how different aspects of power asymmetries work together to affect the individual's abilities (Kimberle Crenshaw, 1994; Iris Marion Young, 1997; Patricia Hill Collins, 1998; Nina Lykke, 2003).

In the analysis of The Murderer's Ape, gender, profession, species and social standing or class have stood out as particularly prominent aspects of selfhood. National and international research on children's literature has taken into account questions pertaining to gender (cf. Roberta Seelinger Trites, 1997; Christine WilkieStibbs, 2002; Victoria Flanagan, 2008). In children's literature, animals have been popular, both as subjects and fictional characters. The use of animals in literature has been pinpointed by scholars such as Arthur N. Applebee (1978), Carolyn L. Burke and Joby G. Copenhaver (2004) and Victoria de Rijke (2008). In interviews, Wegelius has said that his choice of a gorilla as the protagonist enables him to place Sally Jones in settings where she would have been forbidden if she were a human male or female (Örjan Westberg, 2014). Finally, social standing or class is relevant, as it is linked to ownership and the individual's possibilities in life, but also to questions of domination and discrimination.

Starting with the issue of gender, as shown in the quotation at the beginning of this article, Sally Jones' status as neither man nor woman allows her greater freedom than other characters. Here, her outsider status advances a privileged position, but since she is also female, she is not entirely removed from the power dynamics of gender. In Wegelius's fictional society, what would have been inappropriate for human beings emerges as a cross-border that creates opportunities beyond gender (cf. Donna Haraway, 1991). Sally Jones never comments upon her gender, but occasionally the human fictional characters, like the Maharaja, do; Captain Anderson feels the need to comment: "Koskela is a good fellow (...). And so are you. Apart from the fact that you are a she, of course. And a gorilla" (Wegelius, 2017, p. 258). Captain Anderson's words give the reader a clue as to why Sally Jones loves the life at sea; neither species, nor gender nor nationality

\footnotetext{
${ }^{3}$ The story is told in Legenden om Sally Jones (2008), but part of it is also retold in The Murderer's Ape.
} 
matter at sea. Professional skills, loyalty and teamwork do, and both Koskela and Sally Jones are trustworthy professionals.

Sally Jones' liminality can also be discerned in conjunction with profession. Professionally, the protagonist is an extremely competent engineer, but as she is not human, she has to prove her worth. She earns the right to a workstation of her own in Signor Fidardo's repair shop (Wegelius, 2017, Chaps. 15-16). Grudgingly, Signor Fidardo acknowledges Sally Jones' skills: "Not bad at all. For a gorilla, anyway. (...) Not bad for a craftsman, either'” (Wegelius, 2017, p. 101). Sally Jones is, indeed, a celebrity in her profession. When she enlists, one of her shipmates says that she is known to be "one hell of an engineer" (Wegelius, 2017, p. 206). The detailed and in-depth descriptions of engines and instruments underscore the protagonist's professional skills and her understanding of herself. In this case, one could argue that the profession is crucial for Sally Jones' self-image: it overshadows the broader question of gender or species.

Though she is respected for her professional skills, Sally Jones is also envied. Other characters are depicted as sceptical:

Mr. Bullworth was not too happy that Geoff had put me in charge of the throttle valve.

"Was it wise to put all our lives in the hands of a gorilla?" he muttered.

"Dealing with the throttle valve is always part of the grease monkey's job," Geoff said, managing to be serious for once. "And Sally Jones is no worse than any other grease monkey I've sailed with” (Wegelius, 2017, p. 223).

In the novel, Sally Jones' professional skills are her ticket into human society, but she constantly has to prove not only that she is not merely as competent as a human being, but that she is actually better. This is particularly true in her relationships with the male fictional characters, but as Sally Jones never competes with any of the female fictional characters, it can be debated whether the discrimination is based on gender or species.

Specism has rarely been examined within intersectionality; discussions to date relate to ecocriticism and animal studies (Josephine Donovan, 2016; Josephine Donovan and Carol J. Adams, 2007). For understanding The Murderer's Ape, however, specism is central. Even though Sally Jones has human qualities, she never depicts herself as an interspecies creature. She does, however, address the preconceived ideas held by human fictional characters:

When I meet people for the first time, almost everyone treats me as a gorilla. That's only to be expected: after all, I am a gorilla. People usually assume that someone must have trained me to wear human clothes, in the same way bears in circuses have been trained to walk on their hind legs and parrots can be trained to swear. There are not many people who realize that I can think thoughts of my own and understand what people are saying. Not until they get to know me, that is (Wegelius, 2017, p. 127).

Sally Jones' reflections reveal prejudices and problematize the question of species. She challenges the clear-cut boundary between species, not by denying 
her own affiliation to species but her reflections challenge the views on species held by the other fictional characters and, perhaps, by readers. In Wegelius' protagonist, female and posthuman identities merge. Notions of man's unique essence, autonomy and special status challenge the dichotomies, such as the dichotomy between humans and animals. Subject positions are, according to Rosi Braidotti (2002), collective, and not construed as individual expressions or actions. Therefore, the fictional character of Sally Jones does not expect the human fictional characters to immediately perceive her as an individual; she is a gorilla, and expects the others to see her as such. Her abilities to think for herself and to understand people are not expected from animals: to use Braidotti's (2002) and Haraway's (1991) terms, she is an animal-human hybrid, similar to a cyborg.

Sally Jones' liminality, in particular the fact that she is not human, makes it possible for many human characters to objectify her. While on the journey to gather intelligence that will acquit the Chief, Sally Jones reflects upon her vulnerability: "Without someone to help and protect me, I was no more than a gorilla without a master" (Wegelius, 2017, p. 253). Her fear proves to be accurate, as she is betrayed by a shipmate and bestowed as a gift to the Maharaja of Bhapur.

Sally Jones is an animal, in her own opinion as well as in the eyes of other fictional characters. In Cochin, at the office for trades, a desk clerk informs Sally Jones' companion that pets are not allowed and must be left outside (Wegelius, 2017). Prejudice is not confined to the Westerners in Asia. At another office in Cochin, Sally Jones is first acknowledged as an animal and therefore potentially dangerous. When labelled a pet, a domesticated object, she is ignored, thus reinforcing both the division between humans and animals and between wild animals and pets (cf. Braidotti, 2002).

The Maharaja, who receives Sally Jones as a gift, treats her recklessly, though not entirely as an animal. He appoints her aide-de-camp, on the grounds of her prowess in playing chess and knowledge of basic arithmetic (Wegelius, 2017). This acknowledges Sally Jones' skills, without upholding differences between species. The Maharaja initially does this to show his lack of respect for the other human characters rather than his respect for Sally Jones, but he learns to enjoy spending time with her.

Sally Jones' physical appearance distinguishes her from the other characters. Wegelius' illustrations do not anthropomorphise Sally Jones beyond her clothing, which reflect her varied professions: the engineer, the aide-de-camp, and so on. Despite her naturalistic gorilla appearance, the human clothes she wears allow the other characters to disregard the fact that she is an animal. At one point, she reflects on this: "On the way there, I saw several 'wanted' posters with my face drawn on them. They did not look anything like me: all gorillas look the same to human beings" (Wegelius, 2017, p. 193). The materiality of her body is depicted as a paradox; Sally Jones accepts that she is a gorilla, but she is also aware that her physical otherness is the reason why humans might put her in a zoo. The gorilla body gives her strength beyond that of her human counterparts, but it is also her weak point, as it may result in her losing her freedom and read as being objectified. 
The final aspect of Sally Jones' marginalization is economic: she belongs to the working class. Apart from a brief period aboard the Hudson Queen at the beginning of the novel, she owns nothing apart from her clothes, and eventually a turban and an old Underwood typewriter. When working together with the Chief, she might get paid: "We take every job we can get in order to save up money" (Wegelius, 2017, p. 586), though it is never clearly stated that she earns money, only that they try to save money. At the same time, the economically marginalized gorilla is put in situations where she meets and interacts with representatives of high society, either briefly or for a longer period.

Sally Jones' musings about money come across as a critique of a society smitten by greed. Comments on the debaucheries of the Maharaja are delivered in a nonjudgmental tone: "The maharaja was famous for his parties (...). They were splendid feasts with hundreds of dishes, an abundance of expensive wines, orchestras and entertainment provided by buxom dancing girls from Lahore" (Wegelius, 2017, p. 358). However, the juxtaposition of descriptions of senseless spending and of the utter poverty of the countryside of Bhapur comes across as social critique, in particular as it is delivered by the outsider-animal and not by a human fictional character. Sally Jones is more at home among working class people than with the "fat men with tall hats, bushy beards and worried eyes" (Wegelius, 2017 , p. 313), but being an outsider allows her to look upon social and economic injustice in both Europe and Asia.

To recap, the protagonist occupies a liminal status that is utterly unlike that of the other fictional characters when taken as a whole, although aspects of her intersectionality align her with more traditionally marginalized positions: female and working class. The Murderer's Ape is a story about a female among male characters; an ape in a world of human beings; an engineer who is neither a pet nor a caged attraction at a zoo; a character who is not defined by her class or social standing. Instead, Sally Jones proffers a vantage point for evaluating the categories and boundaries that define the other characters.

\section{Positioned Beyond the Readers? Digital Discussions of the Novel}

The above analysis highlights our understandings of the intersectionality of Sally Jones in The Murderer's Ape. We now turn to discussions of the novel in digital environments to examine how other readers-professional readers like ourselves and also young readers-respond to the multifaceted protagonist. We begin by discussing the philosophical basis for our methodology.

Our analysis draws from the field of sociology of literature on two levels: society in literature and literature in society. In other words, the portrayal of society in literature and the image of society thus created must be focused, as well as the notion of literature as a multiplier and intermediary of ideas. To access the latter, as stated by Johan Svedjedal, studies of "receipt within different population groups" (2012/1997, p. 79) are needed. According to Robert Escarpit (1970), readers can be categorized as connoisseurs, professional readers like ourselves who observe, understand and analyse literature and the creation of literature and 
thus the purpose, or intentions of literature, or consumers, whose main focus is to savour literature and decide whether they like or dislike it. The distinction between connoisseurs and consumers must, however, not be seen as a qualitative distinction. Both categories comprise what we understand as engaged readers, although their reasons for reading may differ. For this study, if it is not clear that the post was written by a connoisseur, it has fallen into the consumer category. This analysis focuses on the readers' responses to the intersectional categories presented above.

Connoisseurs and consumers alike tend to mention the protagonist's gender, usually by using the female personal pronoun when referring to the protagonist. This can be seen as a convention; readers categorize characters on the basis of gender, linguistically and on the basis of norms in their own societies. Only a few posts by connoisseurs contain explicit discussions on the depiction of gender in the novel, either to laud the fact that the protagonist is not a damsel in distress (Bokcirkeln, 2015), discuss the troublesome depiction of an all-good, self-sacrificing female protagonist (Bokcirkeln, 2016), or to express satisfaction that the protagonist is portrayed as a strong character (Hanna Höglund, 2014). Sally Jones is perceived a particularly interesting protagonist, as she is a female gorilla in a man's world, whether on the high seas or at the Maharaja's court.

In the posts by consumers, in-depth discussions of gender are absent. A few texts by young readers, usually very short reviews, might even omit the personal pronoun that reveals the protagonist's gender. This omission of gender markers could be the result of a conscious choice, but a more likely explanation is that the post focuses on either the plot or on expressing the reader's opinion of the book without mentioning the protagonist (Vera, 2015). While the adult connoisseurs occasionally comment on or discuss gender in the novel, posts by young readers generally do not. Two exceptions can be found in the comments on a blog, where a teacher, without herself participating, lets her pupils discuss their readings of the novel. Two of these 15-year-old readers make comments on the depiction of gender in the novel, but while the connoisseurs discussed gender in relation with the protagonist, in particular with regard to her professional proficiency, these young readers only comment on the depiction of the fictional human women. Ana Molina is termed likeable but almost too good to be true, "almost a saint" (Myra, 2016), and Maji Sahiba is considered a "wise, assertive, warm-hearted person who could run Bhapur much better than her son does" (Alexandra, 2016). The material does not offer any explanation whether this is the result of young readers finding gender issues more relevant for human fictional characters than the animal protagonist, or whether they perceive the notion of hybridity as being too foreign. In The Murderer's Ape, Sally Jones is the only animal character, consequently, her gender might be seen as of less relevance than her animality to the young readers who posted their reviews.

The protagonist's profession is mentioned in posts by both connoisseurs and consumers. Again, slightly fewer consumers than connoisseurs mention or discuss the protagonist's profession or professional skills. In posts by both categories, the protagonist is described as an engineer, quite often as a very skilled professional. When discussing the protagonist's professional competence, both connoisseurs and 
consumers talk about the protagonist's ability to repair machines, build instruments and her use of a very specialized vocabulary. A few posts by connoisseurs express a particular satisfaction that the female protagonist is an engineer, skills that are typically coded as masculine (Bokcirkeln, 2015). Equally, some adult consumers in the material comment on the portrayal of the protagonist's professional skills or on the specialized vocabulary relating to engineering and instrument making. Posts by young consumers, on the other hand, mention that the protagonist is able to hold the same jobs as her human counterparts (Daniel, 2015; Wherethebookslive, 2015) and that she is an engineer (Mattias, 2015), but there are no examples of young readers discussing the protagonist's professional skills. Here, the dividing line goes between adult and young readers, rather than between connoisseurs and consumers. A feasible explanation of the difference is, naturally, that young readers are likely to have little or no work experience and therefore do not engage in such discussions. Among children and younger readers, it seems as though the detailed descriptions of how to repair an accordion, or what it takes to carry out certain procedures on a steamboat function as a backdrop, authenticating the setting and underscoring the protagonist's humanlike qualities rather than adding to the understanding of the protagonist. The protagonist's kindness, intelligence and loyalty seem to inspire more comments by young readers, possibly due to the fact that they might be relatively unfamiliar with professional life but find themselves thinking of what it means to be human and therefore focus on emotions, the meaning of friendship and on Sally Jones' inner qualities.

The intersectional perspective that generates most comments, the major category, in the digital posts, (and this is true of both connoisseurs and consumers) concerns species. Only a few short texts by consumers ignore the fact that the protagonist is a gorilla (Hanna, 12 år, n.d.). Readers may not per se have reservations about the portrayal of a humanlike animal as a protagonist, with the exception of some teenagers who clearly see the novel as a book for younger readers due to the fact that the protagonist is an animal. ${ }^{4}$

Among the youngest readers, a few posts express reservations about the portrayal of the protagonist as a hybrid creature. A 12-year-old reader states that she found most characters "believable, but not Sally Jones, because gorillas can't talk, fix things on a ship, type and do many other things which humans are capable of doing but gorillas aren't. The story made me think about poor cities and villages" (Lisen, 2016). Though unwilling to accept the humanlike qualities of the gorilla, this reader clearly grasps the parallels between the fiction and her own context.

In posts commenting on species, readers discuss the fact that the protagonist is treated as an object, and not as the ethically and emotionally well-developed individual perceived by readers. From a posthumanist perspective, the tendency to see Sally Jones as an equal, on a par with human beings, could be seen as evidence that the borderlines between the categories of "human" and "animal" are blurred. For some young readers, the fuzzy borders are perceived as a problem. The

\footnotetext{
${ }^{4}$ Some of these young readers do, however, express surprise that a book for children treat themes like domestic abuse (Myra, 2016; Alexandra, 2016).
} 
protagonist's ability to read and write, understand different languages, but not speak are considered to be contradictory (Karin, 2016). By rejecting the choice of an animal protagonist, these young readers differ from the youngest consumers and the older readers, both connoisseurs and consumers, who seemingly find accepting Wegelius' choice of protagonist acceptable. Whether pre-teens and teenagers protect their own liminal status by rejecting the notion of an animal protagonist-a common feature in literature for small children-cannot be concluded based on the posts in the material, but comments raise the question. Readers' objections to having an ape protagonist might even be interpreted as an expression of discomfort with hybridity, though this conclusion cannot be substantiated by the material. Wegelius has created a humanoid but not human protagonist, whose story makes visible discrimination, injustice and prejudices, but also the greatness of the human-or, in the case of Sally Jones, the humanoid-mind.

The way in which importance is attached to the physical body and given expression in the digital posts is important: readers hardly ever comment on Sally Jones' physical appearance, but rather what it means to look different. The comments focus on how the perception of the physical body can incite discrimination. In the posthumanist field, Braidotti emphasises the body's role in the feminist project. She finds the body in the intersection of entities, like materiality and discursivity (2002). For some fictional characters, as well as for some readers, Sally Jones' anatomy and materiality, her physical body, supersede her discursive and symbolic body.

Species is a distinctive category in the posts. The discrepancy in numbers (see Table 2) between connoisseurs and consumers mentioning the protagonist's species can be explained by the fact that the shortest and least informative posts were written by readers in the consumer category, and by the fact that some of the posts by consumers only mention species in the title of the novel. Seemingly, those readers judged it less relevant to mention species than to express their opinion, grade their reading experience or to summarize the plot. When readers of both categories do discuss the implications of the protagonist's species, they do, however, tend to draw parallels between the non-human protagonist and her humanlike qualities. As the protagonist is non-human, an immediate identification is not possible, but Wegelius' choice of a non-human protagonist invites readers of both categories to reflect upon human behaviour, and to draw parallels between the sufferings of the ape and the inequalities in their own contexts (cf. Nikolajeva, 2010, who argues that young readers are to be encouraged to understand the ontological status of the fictional character). Sally Jones is compared to paperless immigrants (Bokcirkeln, 2015), and the prejudices against the ape are compared to ethnic discrimination (Augustpriset, 2014). In some cases, readers' attention seem to be diverted from the fact that the protagonist is an animal, either due to Sally Jones' humanlike qualities, or to the fact that the novel is labelled children's literature, and therefore open to animal protagonists.

As mentioned, all posts by connoisseurs and fifty percent of the posts by consumers mention or discuss species. Slightly older readers either express sympathy for the sweet-natured, intelligent ape, or discuss the treatment of the protagonist from ethical, philosophical or psychological points of view. In these 
Table 2 The number of readers dealing with the analysed themes

\begin{tabular}{lcclc}
\hline & Gender & Profession & Species & Class \\
\hline Connoisseurs (47) & & & & \\
Briefly & 31 & 14 & 27 & 10 \\
In-depth & 3 & 9 & 20 & \\
Consumers (50) & & 8 & 19 & 5 \\
Briefly & 29 & 7 & 16 & 5 \\
In-depth & & & & \\
\hline
\end{tabular}

posts, empathy can be seen as a starting-point in a process of recognition, rather than identification. The depiction of Sally Jones' otherness, due to her species and irrespective of her ethically superior qualities, raises the issue of distinctions and hierarchies between species, and make both connoisseurs and consumers draw parallels between the fictional world and their own reality.

One could argue that the ability to read and write, as well as professional skills, constitute core qualities where the dividing line between human and non-human is not as clear as it once was thought to be (cf. Braidotti, 2002). The use of an animal protagonist allows a shift in perspective for the adult reader. The primate as the protagonist could be expected in a novel for young reader, but Wegelius' novel introduces themes that could not as easily be described as obvious in children's literature, such as domestic violence or political corruption. It is seen as a history lesson, as well as a social critique: "The humanlike Sally represents all the oppressed categories: colonized indigenous people, humiliated and tormented animals, oppressed women" (Björn Gunnarsson, 2014). Adult readers often read the novel as social critique by comparing Sally Jones' living conditions with those of disadvantaged people.

Class is the least frequently mentioned of the four intersectional categories highlighted in our reading. There are comments in posts by readers from both categories, but neither the connoisseurs nor the consumers seem to focus on class markers. Instead, the comments concern society, in particular the gulf between social classes in the fictional society of the 1920s, and the political struggle of the establishment to retain their privileges. Again, a lack of knowledge regarding history can possibly explain why young readers do not comment on or discuss the depiction of Europe or Asia in the early twentieth century. As previously shown, young readers draw parallels to their own society and to the twenty-first century, as do adult consumers and connoisseurs, and discuss the meaning of the novel. They do this when discussing the depiction of the fictional society. One teenage reader concludes that "Wegelius may have tried to show us how slaves felt during the slave trade in the $19^{\text {th }}$ century" (H. Isak, 2016). Another 15-year-old states that the message seems to concern racism and that the ape symbolizes a non-white person. Making the gorilla a symbol does not impress that young reader, who claims that he would have been more impressed, had the protagonist been "a dark-skinned person who grew up in a racist society and was told that she is an ape" (Matti, 2016). For 
young readers like Matti and the previously mentioned Lisen, it seems as though they perceive Sally Jones as a human in disguise (cf. Haraway, 1991) or a symbol for life at an intersectional crossroads.

The comments on class by connoisseurs and consumers tend to be limited to acknowledging the fact that the novel depicts different social strata. This does, however, not mean that readers do not notice or comment on questions pertaining to society. Reflections on social injustice and the treatment of immigrants can be found in texts by connoisseurs and consumers alike, even in texts by young readers. For obvious reasons, no reader sees himself or herself in the role of an ape to the extent that young readers may relate to the protagonist in novels such as the series by Suzanne Collins or Veronica Roth. Quite a few posts do however show that readers feel encouraged to talk about how the perception of a character, in a novel or in real life, may be tainted by preconceived ideas and how prejudices may lead to inequality.

Unlike the other characters, readers have access to the protagonist's inner thoughts. Still, it is possible to argue that the protagonist is positioned beyond the readers, too. In children's literature, animal protagonists are not rare. Sally Jones, however, is portrayed as so humanlike that readers seemingly find it difficult to perceive her as either an animal or a human, or, for that matter, as a female. Hence the existence of texts discussing the protagonist as though she were human, as well as texts questioning the abilities attributed to an animal. In some respect, the transgressive nature of the fictional character seems to put her beyond the readers.

\section{Reflections upon the Significance of the Results}

By contrasting our reading of The Murderer's Ape with those of connoisseurs and consumers we have identified blurred borderlines between young and adult readers, trained and untrained readers and "good" or "bad" literature so that the voices of young readers could be heard (cf. Rachel Falconer, 2009; Sandra Beckett, 2009). First, both connoisseurs and consumers share similar reading experiences. The liminality of the protagonist provokes comments, but also creates problems for some young readers, whose comments indicate a refusal to interpret the status of the protagonist metaphorically. This in turn may be a reminder to educators when organizing their literature classes.

Secondly, these posts demonstrate that readers wish to communicate their thoughts on reading, and digital environments, in particular social media, allow and encourage readers to share their readings. For some young readers, sharing their reading experiences is also part of building a brand, identifying themselves as competent readers (Manderstedt and Palo, 2017, in review). Through their writing, they are forming communities of interpretation at a younger age than previous generations of paper book readers.

Third: A reason for the popularity of the novel, amongst both reader categories, might be the positioning of the protagonist beyond the characters and the readers. The complexity of the protagonist allows readers multiple inroads to the novel: a hero's quest, a love story, an adventure, a historical novel, and so on. 
Intersectional analyses presuppose a fairly high degree of professional training; thus it was not surprising that comments of this nature were more evident among the connoisseurs. The more significant finding was that many of the young readers were able to address these issues. Age is a much less significant determiner of power in digital environments: young readers' voices can be heard on an equal footing with trained adults. By collecting data from two categories of online readers, we have been able to pinpoint what is said, not whose claims are privileged.

We have noticed some significant differences between the readers' responses to The Murderer's Ape and the readers' responses to young adult literature in our previous studies. Few reviews and comments on The Murderer's Ape focus the literary format or the style of the novel. This is especially true about reviews and comments by young readers, perhaps because we ignored material produced in school-related contexts (cf. Palo and Manderstedt, 2016; Manderstedt and Palo, 2017 (in review)). There are posts discussing the gender of the fictional characters but, unlike the readers' responses to the novels in some of our previous studies, the gender of the protagonist is not a major factor for the young readers of The Murderer's Ape. In a study from 2015, the young readers seemed more engaged by questions pertaining to class and society than the readers of The Murderer's Ape, possibly since that study concerns readings of two dystopian novels. It seems as though the purpose of the reading, as well as the novel itself, will have an impact on the online post. What does not change is the eagerness to share the reading experience and the reader's thoughts thereupon.

To sum up, the analyses show that those factors that Sally Jones did not choosegender, profession, species and class-contribute to readers' image of the protagonist. Readers made comments pertaining to these factors, and in particular drew attention to species. Interestingly, readers seem to consider species as a point of departure and a backdrop to their reflections on the qualities not expected in an animal: that is her acquired training, her emotional sensibility and her moral compass. Thus, Sally Jones allows readers multiple inroads to the novel. The portrayal of the protagonist allows both connoisseurs and consumers to respond, and online reviews allows for unhierarchical insights into readers' responses. For future research, studies of this kind of empirical material may yield vital knowledge not only on young readers' responses to certain literary texts, but also on their incentives to digitally discuss literature, their literary literacies and the importance of these venues for making meaning of their reading experiences.

Open Access This article is distributed under the terms of the Creative Commons Attribution 4.0 International License (http://creativecommons.org/licenses/by/4.0/), which permits unrestricted use, distribution, and reproduction in any medium, provided you give appropriate credit to the original author(s) and the source, provide a link to the Creative Commons license, and indicate if changes were made.

\section{References}

Adams, Carol J. (2007). The War on Compassion. In Josephine Donovan and Carol J. Adams (Eds.), The Feminist Care Tradition in Animal Ethics: A Reader (pp. 21-38). New York: Columbia University Press. 
Alexandra. (2016). Boksnack. Mördarens apa. 27 kommentarer. Accessed March 23, 2016 from http:// nyaboksnack3.blogspot.se/2016/01/mordarens-apa.html\#comment-form.

AoIR. (2012). Ethical Decision-Making and Internet Research Recommendations from the AoIR Ethics Working Committee (Version 2.0) Accessed March 23, 2016 from http://aoir.org/reports/ethics2.pdf.

Applebee, Arthur N. (1978). The Child's Concept of Story: Ages Two to Seventeen. Chicago: University of Chicago Press.

Appleyard, Joseph A. (1994). Becoming a Reader: The Experience of Fiction from Childhood to Adulthood. Cambridge: Cambridge University Press.

Aronsson, Mattias. (2015). Den litteraturvetenskapliga receptionsforskningen och internet. En metoddiskussion. Tidskrift för litteraturvetenskap, 45(1), 33-44.

Augustpriset. (2014). Jakob Wegelius om Mördarens apa, Augustpodden del 4, 2014. Accessed March 23, 2016 from http://www.augustpriset.se/om-augustpriset/augustfilmer.

Beckett, Sandra. (2009). Crossover Fiction: Global and Historical Perspectives. New York: Routledge.

Bokcirkeln. (2015). Bokcirkeln del ett: “En bok att läsa i pyjamas.” Accessed March 23, 2016 from https://svenska.yle.fi/artikel/2015/12/26/bokcirkeln-del-ett-en-bok-att-lasa-i-pyjamas.

Bokcirkeln. (2016). Bokcirkeln del tre: “̈̈r Sally Jones gorillornas Jesus?” Accessed March 23, 2016 from https://svenska.yle.fi/artikel/2016/01/09/bokcirkeln-del-tre-ar-sally-jones-gorillornas-jesus.

Braidotti, Rosi. (2002). Metamorphoses: Towards a Materialist Theory of Becoming. Cambridge: Polity Press.

Burke, Carolyn, and Copenhaver, Joby G. (2004). Animals as People in Children's Literature. Language Arts, 81(3), 205-213.

Collins, Patricia Hill. (1998). It's All in the Family: Intersections of Gender, Race, and Nation. Hypatia, 13(3), 62-82.

Crenshaw, Kimberle. (1994). Mapping the Margins Intersectionality, Identity Politics, and Violence Against Women of Color. In Martha Albertson Fineman and Roxanne Mykitiuk (Eds.), The Public Nature of Private Violence: The Discovery of Domestic Abuse (pp. 93-118). New York: Routledge.

Daneback, Kristian. (2006). Love and Sexuality on the Internet. Diss. Göteborg: Göteborgs universitet.

Daniel. (2015). Vivaldisexorna.blogg.se: Bok recension Daniel 6a. Accessed March 23, 2016 from http:// vivaldisexorna.blogg.se/2015/may/bokrecension-daniel-6a.html.

de Rijke, Victoria. (2008). Duck. London: Reaktion.

Donovan, Josephine. (2016). The Aesthetics of Care: On the Literary Treatment of Animals. New York: Bloomsbury Publishing.

Escarpit, René. (1970). Litteratursociologi. Stockholm: Wahlström \& Widstrand.

Falconer, Rachel. (2009). The Crossover Novel: Contemporary Children's Fiction and Its Adult Readership. London: Routledge.

Flanagan, Victoria. (2008). Into the Closet: Cross-dressing and the Gendered Body in Children's Literature and Film. New York: Routledge.

Furuland, Lars. (2012/1997). Litteratur och samhälle. In Johan Svedjedal (Ed.), Litteratursociologi: texter om litteratur och samhälle (pp. 13-50), 2nd ed. Lund: Studentlitteratur.

Gunnarsson, Björn. (2014). Sally Jones är tillbaka! Accessed March 18, 2016 from http://www.hd.se/ kultur/boken/2014/04/22/sally-jones-ar-tillbaka/.

Hall, Geoff. (2005). Literature in Language Education. Basingstoke: Palgrave Macmillan.

Hall, Geoff. (2009). Texts, Readers-and Real Readers. Language and Literature, 18(3), 331-337.

Hanna, 12 år. (n.d.). Mördarens apa Av Jakob Wegelius. Accessed March 18, 2016 from http://kpwebben. se/bokrecensioner/.

Haraway, Donna. (1991). Simians, Cyborgs and Women: The Reinvention of Nature. New York: Routledge.

Hayn, Judith, Kaplan, Jeffrey S., and Clemmons, Karina R. (2016). Teaching Young Adult Literature Today: Insights, Considerations, and Perspectives for the Classroom Teacher, 2nd ed. Lanham: Rowman \& Littlefield Publishers.

Isak, H. (2016). Boksnack. Mördarens apa. 27 kommentarer. Accessed March 23, 2016 from http:// nyaboksnack3.blogspot.se/2016/01/mordarens-apa.html\#comment-form.

Hine, Christine. (2015). Ethnography for the Internet: Embedded, Embodied and Everyday. London: Bloomsbury Academic.

Höglund, Hanna. (2014). Gorillans sorgesaing. Accessed December 2, 2015 from http://www.expressen. se/kultur/gorillans-sorgesang/.

Karin. (2016). Boksnack. Mördarens apa. 27 kommentarer. Accessed March 23, 2016 from http:// nyaboksnack3.blogspot.se/2016/01/mordarens-apa.html\#comment-form. 
Kozinets, Robert. (2010). Netnography: Doing Ethnographic Research Online. Los Angeles: SAGE.

Lisen. (2016). Lisen's Reviews > Mördarens apa. May 3, 2016. Accessed May 23, 2016 from http://www. goodreads.com/review/show/1614838556?book_show_action=true\&.

Lykke, Nina. (2003). Intersektionalitet—ett användbart begrepp för genusforskningen. Kvinnovetenskaplig tidskrift, 24(1), 47-56.

Mackey, Margaret. (2011). Narrative Pleasures in Young Adult Novels, Films, and Video Games. Houndmills: Palgrave Macmillan.

Manderstedt, Lena and Palo, Annbritt. (2017). En (skol)genre på rymmen: Bokrecensionen online (in review).

Manderstedt, Lena, and Palo, Annbritt. (2015). Riter, röster och roller. Unga läsare om konvergerad litteratur. Tidskrift för litteraturvetenskap, 2(3), 79-88.

Manderstedt, Lena, and Palo, Annbritt. (2009). Världar att besöka eller bebo: Fan-gemenskaper som litterära mötesplatser. Tidskrift för litteraturvetenskap, 39(3-4), 39-50.

Matti. (2016). Boksnack. Mördarens apa. 27 kommentarer. Accessed March 23, 2016 from http:// nyaboksnack3.blogspot.se/2016/01/mordarens-apa.html\#comment-form.

Mattias. (2015). Vivaldisexorna.blogg.se: Bokrecension, Mattias. Accessed March 23, 2016 from http:// vivaldisexorna.blogg.se/2015/may/bokrecension-2.html.

Myra. (2016). Boksnack. Mördarens apa. 27 kommentarer. Accessed March 23, 2016 from http:// nyaboksnack3.blogspot.se/2016/01/mordarens-apa.html\#comment-form.

Nikolajeva, Maria. (2014). Reading for Learning: Cognitive Approaches to Children's Literature. Amsterdam: John Benjamins Press.

Nikolajeva, Maria. (2010). Power, Voice and Subjectivity in Literature for Young Readers. New York/ London: Routledge.

Nussbaum, Martha C. (2003). Upheavals of Thought: The Intelligence of Emotions. Cambridge: Cambridge University Press.

Palo, Annbritt and Manderstedt, Lena. (2011). Negotiating Norms of Gender and Sexuality Online. In Mariah Larsson and Ann Steiner (Eds.), Interdisciplinary Approaches to Twilight: Studies in Fiction, Media and a Contemporary Cultural Experience (pp. 143-158). Lund: Nordic Academic Press.

Palo, Annbritt, and Manderstedt, Lena. (2016). Värdegrund på undantag?: Om normbrytande flickmekaniker i litteratursamtal online och i skoluppgifter. In Heidi Höglund and Ria HeiläYlikallio (Eds.), Framtida berättelser: Perspektiv på nordisk modersmålsdidaktisk forskning och praktik (pp. 121-142). Vasa: Åbo Akademi.

Purnama, Marcella and Davis, Mark. (2016). Authors, Get Thee to Social Media: Explaining the Rise and Rise of YA Books. Accessed April 12, 2016 from http://theconversation.com/authors-get-thee-tosocial-media-explaining-the-rise-and-rise-of-ya-books-57281.

Sipe, Lawrence R. (2007). Storytime: Young Children's Literary Understanding in the Classroom. New York: Teachers College Press.

Statens medieråd. (2017). Ungar \& medier 2017. Stockholm: Statens medieråd. https://statensmedierad. se/publikationer/ungarochmedier/ungarmedier2017.2344.html.

Steiner, Ann. (2012a). Digital litteraturkritik. In Christina Lenemark (Ed.), Litteraturens nätverk. Berättande på internet (pp. 51-63). Lund: Studentlitteratur.

Steiner, Ann. (2012b). Litteraturen i mediesamhället. Lund: Studentlitteratur.

Svedjedal, Johan. (2012/1997). Det litteratursociologiska perspektivet. In Johan Svedjedal (Ed.), Litteratursociologi: texter om litteratur och samhälle (pp. 73-102). Lund: Studentlitteratur.

Sveningsson, Malin, Lövheim, Mia, and Bergquist, Magnus. (2003). Att fänga nätet kvalitativa metoder för Internetforskning. Enskede: TPB.

Söderlund, Petra. (2012). Med livet som insats-om bokprat på internet. In Ulla Carlsson and Jenny Johannisson (Eds.), Läsarnas marknad, marknadens läsare-en forskningsantologi (pp. 193-206). SOU 2012:10. Stockholm: Fritzes.

Trites, Roberta Seelinger. (1997). Waking Sleeping Beauty: Feminist Voices in Children's Novels. Iowa City: University of Iowa Press.

Vera. (2015). Jakob Wegelius: Mördarens apa. September 8, 2015. Accessed March 18, 2016 from http:// mobi.helmet.fi/sv-FI/Barn/Jakob_Wegelius_Mordarens_apa(72724).

Westberg, Örjan. (2014). Härifrån till evigheten med Sally Jones. Accessed February 5, 2015 from 2 http://www.dt.se/noje/harifran-till-evigheten-med-sally-jones.

Wegelius, Jakob. (2017). The Murderer's Ape. Translation by Peter Graves. New York: Delacorte Press.

Wherethebookslive. (2015). Mördarens apa. April 6, 2015. Accessed December 2, 2015 from https:// wherethebookslive.wordpress.com/2015/04/06/mordarens-apa. 
Wilkie-Stibbs, Christine. (2002). The Feminine Subject in Children's Literature. New York: Routledge. Young, Iris Marion. (1997). Intersecting Voices: Dilemmas of Gender, Political Philosophy, and Policy. Princeton: Princeton University Press. 